\author{
Anna Kwiecień* \\ Katarzyna Żak ${ }^{* * *}$
}

\title{
BUDOWANIE RELACJI W STRUKTURACH SIECIOWYCH W PROCESIE TWORZENIA WARTOŚCI KLIENTA I PRZEDSIĘBIORSTWA
}

\section{WSTĘP}

Współcześnie obserwuje się odchodzenie od charakterystycznej w epoce przemysłowej struktury organizacyjnej w kierunku struktury sieciowej opartej na relacjach.

Powstanie relacji międzyorganizacyjnych jest zgodne $\mathrm{z}$ ogólną tendencją rynkową opisywaną w literaturze, w której podkreśla się, że w miejsce transakcji na runku, wchodzą relacje. Szerzej pojmowane wzajemne relacje, rozumiane jako więzi z klientami i partnerami, w których cele stron osiagane są przez obustronną wymianę i realizację poczynionych obietnic.

Nadrzędnym celem funkcjonowania pozostaje nadal tworzenie wartości. Zmieniają się jednak sposoby jej kreacji. Wynika to z potrzeby ciagłego dostosowywania się do warunków otoczenia oraz z faktu, że samodzielna realizacja wszystkich funkcji wewnątrz przedsiębiorstwa jest praktycznie niemożliwa. Wyznaczają je potrzeby i postawy klientów, które wymagają specjalizacji, kompetencji w kluczowych dziedzinach działalności dla firmy i właściwych relacji.

W świetle takich założeń celem niniejszego opracowania jest zaprezentowanie relacji jako istotnego elementu struktur sieciowych warunkującego kreowanie wartości, ze szczególnym uwzględnieniem relacji z klientami.

\section{TWORZENIE WARTOŚCI - KONCEPTUALIZACJA PROBLEMU}

Procesy składające się na funkcjonowanie współczesnych organizacji gospodarczych przebiegają w warunkach dużej zmienności i niepewności otoczenia. W takich warunkach zmienia się filozofia myślenia o biznesie i determinan-

\footnotetext{
"Doktor, Uniwersytet Ekonomiczny w Katowicach.

** Doktor, Uniwersytet Ekonomiczny w Katowicach.
} 
tach jego sukcesu. Jednym z zasadniczych celów strategicznych współczesnego przedsiębiorstwa jest wzrost jego wartości, co znajduje odzwierciedlenie w nowym paradygmacie zarządzania strategicznego (zob. rys. 1).

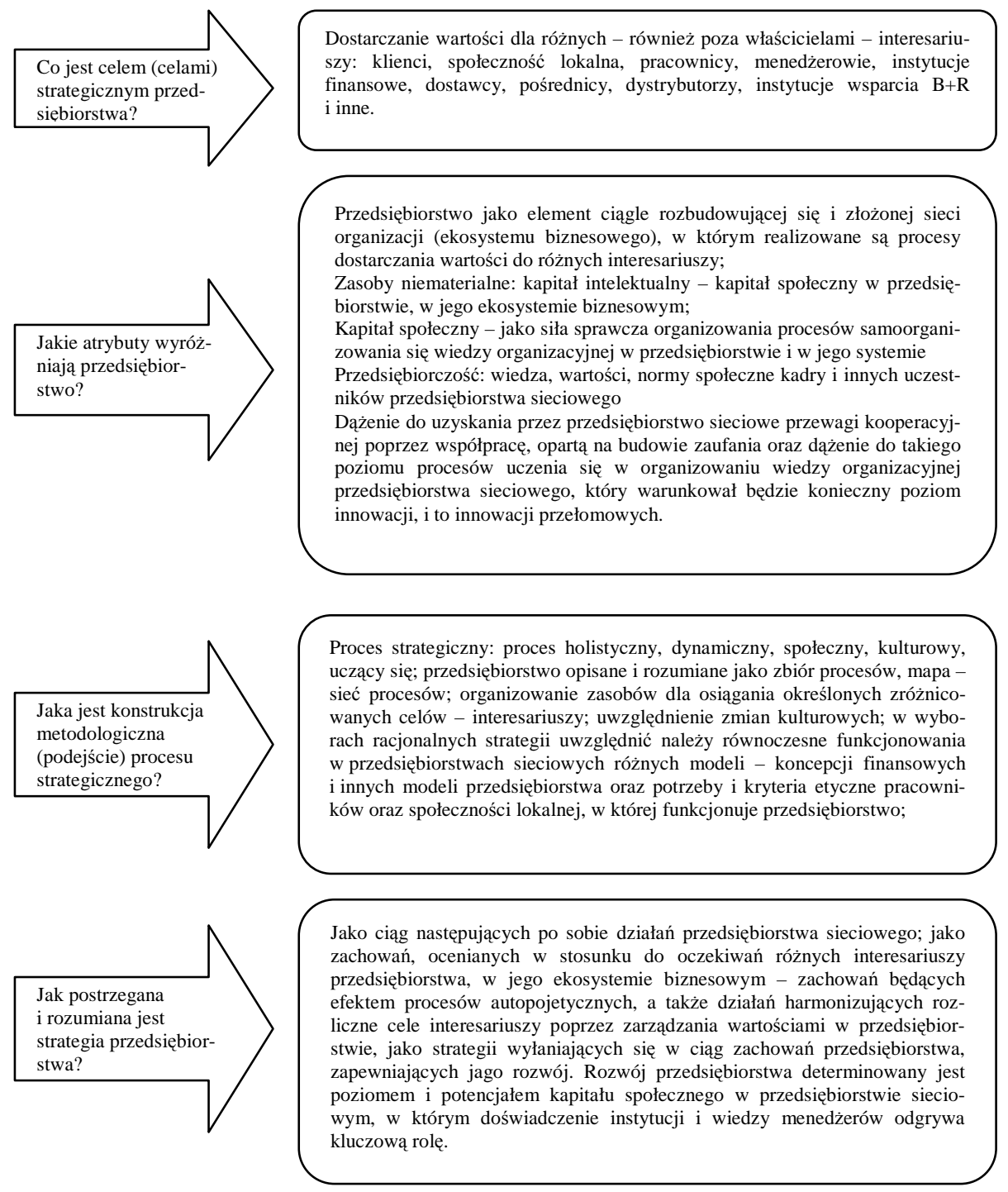

Rys. 1 Elementy nowego paradygmatu zarządzania strategicznego

Źródło: opracowanie własne na podstawie B. Woźniak-Sobczak (red.), Instrumenty zarzqdzania przedsiębiorstwem przez finanse, Wydawnictwo Akademii Ekonomicznej w Katowicach, Katowice 2010, s. 18-19. 
Koncepcja kreowania wartości ma już swoją dość długą historię ${ }^{1}$. Punktem wyjścia dla niniejszego artykułu jest założenie, iż zarządzanie przez wartość zawiera zasady, propozycje i rozwiązania w zakresie kreowania relacji oraz podejmowania strategicznych i operacyjnych decyzji, których celem jest maksymalizacja wartości przedsiębiorstwa dla właścicieli oraz innych interesariuszy, takich jak: klienci, pracownicy, dostawcy, wierzyciele, społeczności lokalne oraz społeczeństwa (zob. tab. 1). W konsekwencji oznacza to, iż maksymalizacja wartości dla akcjonariuszy jest niemożliwa bez uwzględnienia korzyści osiaganych przez pozostałych interesariuszy ${ }^{2}$.

Tabela 1

Wartość dodana dla poszczególnych grup interesariuszy

\begin{tabular}{|c|c|c|}
\hline $\begin{array}{c}\text { Grupa } \\
\text { interesariuszy }\end{array}$ & Wniesiony wkład & Oczekiwana wartość dodana \\
\hline Menedżerowie & Umiejętności, wiedza, talent, czas & $\begin{array}{l}\text { Sprawiedliwy dochód, dobre warunki } \\
\text { pracy }\end{array}$ \\
\hline Akcjonariusze & Kapitał finansowy & Maksymalizacja zwrotu z kapitału \\
\hline Pracownicy & Czas, wiedza, umiejętności & Pewny dochód, dobre warunki pracy \\
\hline Kredytodawcy & $\begin{array}{l}\text { Pożyczki, instrumenty dłużne, środki } \\
\text { finansowe, }\end{array}$ & Zwrot kapitału i oprocentowania środków \\
\hline Klienci & Dochód & $\begin{array}{l}\text { Wartość pieniądza w jakości produktu lub } \\
\text { usługi }\end{array}$ \\
\hline Dostawcy & $\begin{array}{l}\text { Zasoby potrzebne do uzyskania } \\
\text { produktu finalnego }\end{array}$ & Sprawiedliwa cena, monopol dostawy \\
\hline $\begin{array}{l}\text { Społeczności } \\
\text { lokalne }\end{array}$ & Infrastruktura, ulgi, przestrzeń & $\begin{array}{l}\text { Jakość życia mieszkańców, miejsca pracy } \\
\text { dla społeczności lokalnej }\end{array}$ \\
\hline Państwo & $\begin{array}{l}\text { Infrastruktura regulacyjna konkurencji } \\
\text { rynkowej, budowa potencjału } \\
\text { wzrostowego kraju }\end{array}$ & $\begin{array}{l}\text { Równe warunki konkurencji, wzrost } \\
\text { zamożności obywateli }\end{array}$ \\
\hline
\end{tabular}

Źródło: B. Dobiegała-Korona, A. Herman (red), Wspótczesne źródta wartości przedsiębiorstwa, Difin, Warszawa 2006, s. 269, [za:] C. W. L. Hi11, T. M. J o n e s, Stakeholder Agency Theory, ,Journal of Management Studies” 1992, Vol. 2.

Mamy więc do czynienia z koniecznością zapewnienia zgodnej koegzystencji i budowania trwałej równowagi między różnymi interesami jednostek, grup, organizacji, lokalnych i centralnych organów administracji. Podstawą tzw. kapitalizmu grup interesu jest przekonanie, że przedsiębiorstwo jest integralną częścią społeczeństwa, a nie jego oddzielną częścią, dążącą wyłącznie do realizacji celów ekonomicznych. Jak pisze P. Drucker (...) wolne przedsiębiorstwo działa-

${ }^{1}$ Fundamentów koncepcji Value Based Management można poszukiwać w pracach takich autorów jak: A. Marshall, M. Miller, H. Modiglianieg, W. Skarp, F. Black, M. Scholes, Jansen, W. Meckling, A. Rapaport, T. Copeland, T. Koller, J. Murrin, G. B. Stewart, R. S. Kaplan, D. P. Norton, L. Edvisson, M.S. Malone; por. A. S z a ble w s ki, Zarzqdzanie wartościa przedsiębiorstwa, „Kwartalnik Nauk o Przedsiębiorstwie”, październik 2006, nr 1.

${ }^{2}$ M. J e r ze mow s k a, Nadzór korporacyjny, PWE, Warszawa 2002, s. 31. 
jące $w$ warunkach wolności ekonomicznej nie może istnieć tylko dlatego, że jest dobre dla biznesu; sens jego istnienia polega na tym, że jest potrzebne spoteczeństwu ${ }^{3}$.

\section{PRZESŁANKI TWORZENIA RELACJI}

Intencje tworzenia sieci relacji mogą być różne, choć można stwierdzić, że wszystkie one bezpośrednio lub pośrednio wpływają na kształtowanie wartości. Jednym z wyznaczników tworzenia relacji może być stwierdzenie, że współczesna gospodarka wymaga nastawienia kooperacyjnego, które należy rozumieć jako wspólne, zespołowe działanie, u podstaw którego leży możliwość znacznego obniżenia kosztów i zwiększenia efektywności działania ${ }^{4}$. Można również powiedzieć, że podstawową przyczyną nawiązywania relacji jest dążenie do wzrostu rentowności działania. Oznacza to, że przez współpracę firmy mogą właśnie aktywnie ograniczać koszty działalności, dzielić ryzyko, pozyskiwać wyjątkową wiedzę, uzyskać dostęp do rynków zbytu oraz transferu technologii ${ }^{5}$.

$\mathrm{W}$ obecnych czasach samodzielna realizacja wszystkich funkcji wewnątrz przedsiębiorstwa jest praktycznie niemożliwa. Znaczenia nabiera specjalizacja, kompetencje w kluczowych dziedzinach działalności dla firmy i właściwe relacje. Chcąc produkować wysokiej jakości produkt lub świadczyć wysokiej jakości usługi firmy muszą zawierać sojusze i współpracować z innymi podmiotami będącymi specjalistami w danej dziedzinie. Oznacza to, że muszą tworzyć relacje, to bowiem pozwala poprawiać innowacyjność i konkurencyjność firmy. Ponadto sukces sieci determinowany jest bardzo wysoką specjalizacją, wzajemnym zaufaniem partnerów, kulturą pracy, rygorystycznym zarządzaniem kosztami oraz szybkością i efektywnością wymiany zasobów w ramach siecí.

W literaturze dostrzec można wiele rożnych przykładów motywów nawiązywania współpracy, wśród nich najczęściej wymieniane są: obniżenie kosztów, zwiększenie efektywności wykorzystania zasobów, uatrakcyjnienie własnej oferty, możliwość wejścia na nowe rynki, obniżenie ryzyka, uzyskanie dostępu do nowych technologii, wzrost innowacyjności itp. ${ }^{7}$ Słusznym podsumowaniem w tej kwestii może być stwierdzenie J. Niemczyka ${ }^{8}$, który, istotę strategii sieci dostrzega w kształtowaniu innowacyjnych układów współpracy, dzięki którym

\footnotetext{
${ }^{3}$ P. F. Dru c ke r, Myśli przewodnie Druckera, MTBiznes, Warszawa 2002, s. 34.

${ }^{4}$ D. Nowak, Zarzadzanie międzyorganizacyjnymi relacjami kooperacyjnymi $w$ przedsiębiorstwach przemystowych, Wydawnictwo UE w Poznaniu, Poznań 2012, s. 5.

${ }^{5}$ M. B engts son, S. Kock, Coopetition in Business Networks - to Cooperate and Compete Simultaneously, „Industrial Marketing Management” 2000, Vol. 14, No. 3, s. 411-426.

${ }^{6} \mathrm{~J}$. B ril m a n, Nowoczesne koncepcje i metody zarzqdzania, PWE, Warszawa 2002, s. 431.

${ }^{7}$ Szerzej na ten temat: D. Now a k, op. cit., s. 164 i n.

${ }^{8} \mathrm{~J}$. Ni e m c z y k, Wyróżniki, budowa i zachowania strategiczne układów outsourcingowych, AE, Wrocław 2006.
} 
możliwe staje się przejmowanie wartości dodanej z tytułu uczestnictwa w takich układach (sieciach) współpracy. Chęć pozyskania szeroko rozumianej wartości dodanej, pochodzącej z różnych źródeł, wyraża ogólną intencję tworzenia relacji.

Ponadto sieci relacji i kontaktów mogą stanowić podwójne źródło przewagi konkurencyjnej. Po pierwsze, sieci można traktować jako nielimitowany i niezastępowalny zasób, kreujący wartość sam w sobie. Po drugie, jako środek ułatwiający dostęp do nielimitowanych, wartościowych zasobów i umiejętności. Sieć relacji stanowi więc źródło kreacji niekopiowalnych, generujących wartość zasobów ${ }^{9}$. Jest ona również zasobem unikatowym i specyficznym, gdyż wyrosłym z osobistych kontaktów przedstawicieli przedsiębiorstwa i ukształtowanym w sposób odpowiadający jego konkretnym potrzebom.

\section{RELACJE JAKO ELEMENT STRUKTUR SIECIOWYCH}

Obecnie relacje (więzi relacyjne) stanowią podstawę formowania i funkcjonowania sieci międzyorganizacyjnych ${ }^{10}$.

Pojęcie relacja dotyczy pewnego wzorca wzajemnych zachowań przedsiębiorstw w określonym czasie. Należy je postrzegać jako oddziaływania przyjmujące bardziej uporządkowane i utrwalone formy, obejmujące względnie trwałe transakcje, przepływy zasobów oraz inne kontakty powstające między dwoma lub większą liczbą organizacji oraz między daną organizacją (organizacjami) i jej otoczeniem.

Można wyróżnić cztery podstawowe kategorie relacji przedsiębiorstwa z innymi podmiotami rynkowymi:

- relacje pionowe wsteczne (z dostawcami) - ze wszystkimi podmiotami, które zapewniają przedsiębiorstwu niezbędne czynniki produkcji,

- relacje pionowe frontalne (z nabywcami) - z klientami lub pośrednikami zajmującymi się dystrybucją,

- bezpośrednie relacje poziome (z graczami branżowymi) - z innymi podmiotami z tej samej branży, którzy są lub mogą być konkurentami danej firmy,

- pośrednie relacje poziome (z graczami spoza branży) - z dostawami dóbr komplementarnych lub substytucyjnych, bazując na formie aliansu lub rywalizacji.

Przy czym podział relacji na bezpośrednie i pośrednie nie jest oczywisty.

${ }^{9}$ E. Głuszek, Zarzqdzanie zasobami niematerialnymi przedsiębiorstwa, Wydawnictwo AE we Wrocławiu, Wrocław 2004, s. 242.

${ }^{10}$ Por. M. B rzeziński, Organizacja i sterowanie produkcjq, Placet, Warszawa 2002, s. 281; R. Blażla k, Struktury sieciowe a innowacyjność przedsiębiorstw, [w:] K. O w c zar e k (red.), Klastry w gospodarce regionu, Monografie Politechniki Łódzkiej, Łódź 2010, s. 30; M. Górzyński, W. Pander, P. Koć, Tworzenie zwiazków kooperacyjnych między MSP oraz MSP $i$ instytucjami otoczenia biznesowego, PARP, Warszawa 2006, s. 16 
Ogół relacji jakie można wyróżnić na współczesnych rynkach przedstawia rys. 2 .

Odpowiednio zbudowane i wykorzystane relacje tworzą kapitał relacyjny postrzegany jako niematerialny element aktywów firmy, na które składa się wartość wszystkich stosunków przedsiębiorstwa z różnymi podmiotami otoczenia.

Kapitał relacyjny przedsiębiorstwa, zwany również zewnętrznym kapitałem strukturalnym, określa stopień i zakres powiązania przedsiębiorstwa z kontrahentami oraz stopień rozpoznania rynku zarówno zaopatrzenia, jak i zbytu ${ }^{11}$. W skład tego kapitału wchodzą struktury służące do utrzymania właściwych relacji z otoczeniem obejmujące: system rekrutacji, sieci sprzedaży, projekty badawczorozwojowe, bazy klientów, markę, reputację, partnerstwo strategiczne itp. ${ }^{12}$

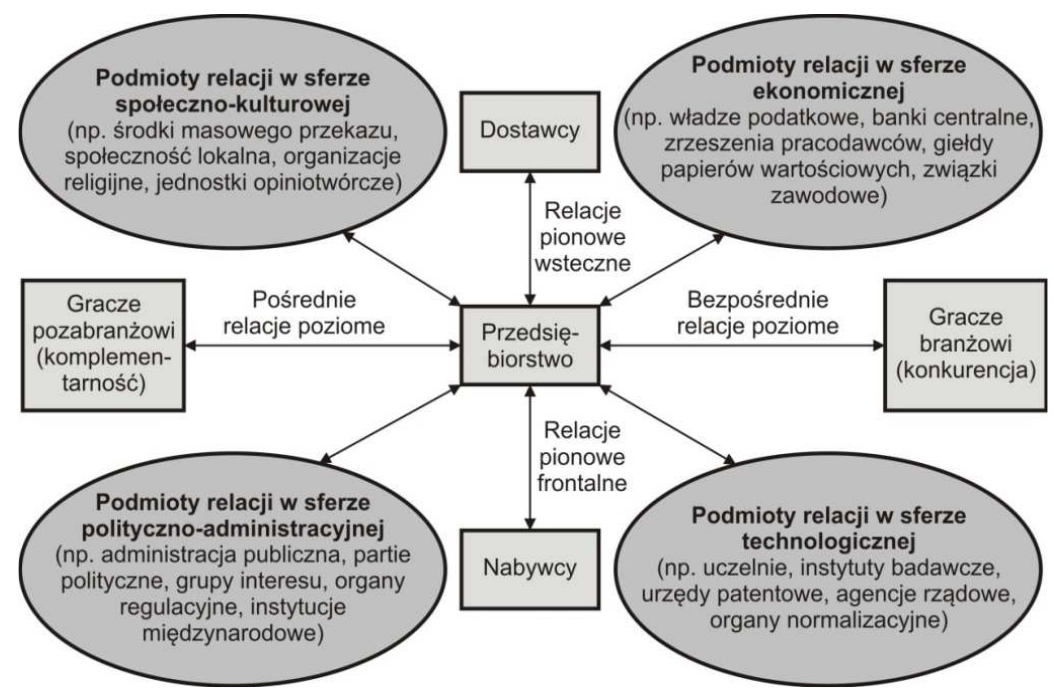

Rys. 2. Przedsiębiorstwo i jego sieć relacji

Źródło: B. De Wi t, R. M e ye r, Synteza strategii, PWE, Warszawa 2007, s. 219.

Ponadto składają się nań zewnętrzne relacje organizacji:

- jej sieć: dostawców, dystrybutorów, organizacji hobbystycznych. Analiza sieci powiązań organizacji powinna koncentrować się w szczególności na intensywności i rozległości kontaktów, jakie organizacja posiada i jakie są istotne dla

${ }^{11} \mathrm{U}$ niektórych autorów kapitał relacyjny traktowany jest jako sieć relacji zewnętrznych i wewnętrznych przedsiębiorstwa, por. J. S. Kard a s, Budowanie relacji w zarzqdzaniu zasobami ludzkimi, Wydawnictwo Studia Emka, Warszawa 2009. Jednakże w kontekście organizacji sieciowych większe znaczenie przypisuje się relacjom międzyorganizacyjnym - wewnętrznym dla sieci.

${ }^{12}$ A. Gó r l a c z y k, Leif Edvinsson na konferencji Skandii, http://ceo.cxo.pl/news/39471/Leif.Edvinsson.na.konferencji.Skandii.html 
jej funkcjonowania. Warto zwrócić też uwagę, czy powiązania te wykorzystywane są w najlepszy możliwy sposób; czy sieć daje organizacji dostęp do dodatkowych kompetencji, zasobów finansowych, mediów itp.?;

- marka: podstawowymi aspektami badanymi w tym obszarze są podejście, preferencje, reputacja itp. Ważnymi pytaniami definiującymi poziom tych czynników mogą być: czy firma jest dobrze znana, czy grupa docelowa organizacji darzy ją wysokim zaufaniem, czy rynek postrzega firmę jako mającą silną przewagę konkurencyjną?;

- klienci: stanowią oni nie tylko bezpośrednie źródło generowania strumieni pieniężnych, ale też są jednym z najważniejszych źródeł przewagi konkurencyjnej. Czy klienci postrzegają firmę jako ich strategicznego dostawcę, czy raczej jako partnera? Czy klienci firmy decydują o jej wizerunku wśród jej konkurentów? Czy klienci są lojalni i na jak długi okres? Czy firma ma bliskie relacje ze swoimi klientami? Warto także dodać, że im więcej wie ona o swoich klientach oraz im silniejsze relacje udało jej się nawiązać z klientami tym trudniej będzie im podjąć decyzję o odejściu ${ }^{13}$.

W tym miejscu warto podkreślić, że w przypadku sieci trzeba w specyficzny sposób podejść do rozróżniania relacji wewnętrznych i zewnętrznych.

W typowej organizacji relacje wewnętrzne dotyczą przede wszystkim wszelkich relacji pracowników danej firmy, zaś zewnętrzne dotyczyć mogą innych podmiotów - dostawców, kooperantów itp. oraz klientów. Jeśli jednak weźmiemy pod uwagę, że struktura sieciowa rozumiana jest jako zespół podmiotów i względnie trwałych więzi między nimi, to automatycznie musimy dokonać pewnej redefinicji podziału relacji.

W przypadku omawiania relacji w sieci przyjmujemy, że relacje międzyorganizacyjne, ale z podmiotami wchodzącymi w skład sieci i współtworzącymi ją, stanowią również relacje wewnętrzne, zaś jako zewnętrze przyjmujemy relacje z ostatecznymi klientami spoza sieci.

\section{TWORZENIE RELACJI Z KLIENTAMI JAKO DETERMINANTA WZROSTU WARTOŚCI PRZEDSIĘBIORSTWA}

C. K. Prahalad i V. Ramaswamy zwracają uwagę na szczególną rolę klientów we współtworzeniu wartości firmy. Istota tego procesu polega na interakcjach pomiędzy nimi, budowaniu doświadczenia ${ }^{14}$.

Perspektywa spojrzenia na klienta z punktu widzenia firmy i samego klienta na przedsiębiorstwo jest odmienna. Z punktu widzenia firmy, klienci są cennym

${ }^{13} \mathrm{P}$. Hof man-B ang, H. M arti n, IC Rating na tle innych metod oceny kapitatu intelektualnego, http://www.e-mentor.edu.pl/artykul/index/numer/11/id/193

${ }^{14}$ C. K. Prahalad, V. Ramas wamy, Przyszłość konkurencji, PWE, Warszawa 2005, s. $65-67$. 
zasobem, podstawą egzystencji i głównym źródłem wartości gdyż generują zyski i gotówkę, niezbędną dla egzystencji i rozwoju przedsiębiorstwa, zapewniają realizację celów wszystkich grup interesu/pracowników, właścicieli, dostawców, wierzycieli, władz lokalnych i budżetu państwa, a także tworzą warunki dla bezpiecznego obrotu i wzrostu gospodarczego.

Natomiast z perspektywy spojrzenia samego klienta podstawowe pytania dotyczą przede wszystkim wartości, jakie klient nabywa zakupując określone produkty i/lub usługi. To właśnie zrozumienie wartości postrzeganych przez klienta i jemu dostarczanych, może być trwałym źródłem przewagi konkurencyjnej we współczesnych warunkach konkurencji.

Identyfikacja wartości dostarczanych docelowym klientom i określonym segmentom rynku staje się jednym z największych wyzwań strategicznych firmy. Obecnie firmy konkurują wartościami oferowanymi klientom, a ściślej pakietem korzyści dla klienta. C. K. Prahalad i V. Ramaswamy stwierdzają, że przyszłość konkurencji wiąże się całkowicie z nowym podejściem do tworzenia wartości, opartym na współtworzeniu wartości przez klientów firmy. Istota klienta, jako współtwórcy wartości przedsiębiorstwa, wiąże się z odejściem od oddzielenia funkcji zarządzania produkcją od funkcji konsumpcji oraz traktowania rynku, jako forum wymiany wartości między firmą i klientem. Ta ścisła współpraca pomiędzy klientami i przedsiębiorstwem musi być oparta na zaangażowaniu obu stron w budowanie wartości, a wartość przedsiębiorstwa będzie rosła wraz ze wzrostem doświadczeń współtworzenia.

Zasadniczą kwestią dotyczącą współtworzenia wartości przez klientów jest określenie tego, co klienci wnoszą do przedsiębiorstwa - jakie strumienie generowane do przedsiębiorstwa przez klientów tworzą jego wartość. Wartość klienta można określić w dwojaki sposób. W wąskim znaczeniu wartość klienta ograniczana jest do rentowności transakcji lub rentowności w cyklu życia klienta w firmie. Jednak współcześnie coraz częściej wymagane jest szersze spojrzenie na klienta $-\mathrm{z}$ perspektywy wszystkich strumieni kreowanych przez niego do firmy oraz dążenie do wyceny tych strumieni. W takim znaczeniu do strumieni wartości wnoszonych przez klienta należy zaliczyć: pieniądze, dobra, czynności, czas, informację, status, uczucia i emocje oraz przyciagnięcie nowych klientów ${ }^{15}$.

Wymienione strumienie mają swoją wymierną wartość, która znajduje swoje odzwierciedlenie w wartości klienta oraz wartości przedsiębiorstwa. Strumienie pieniężne zapewniają przedsiębiorstwu bieżącą zdolność finansową, zaś informacje, budowa wizerunku zapewniają rekonfigurację zasobów przedsiębiorstwa w dłuższym okresie, ograniczając ryzyko dotyczące kierunków inwestycji i źródeł wzrostu wartości przedsiębiorstwa.

${ }^{15}$ B. Dobi e gała-Koron a, Wartość klienta czy wartość dla klienta?, „Kwartalnik Nauk o Przedsiębiorstwie”, październik 2006, nr 1. 
Krytycznym elementem kreowania wartości klienta oraz wartości przedsiębiorstwa jest określenie wartości dla klientów. Jedno z podejść mówi, że jest to różnica między przewidywaną oceną wszystkich korzyści, jakie może otrzymać klient a nakładem, jaki musi on ponieść, aby te korzyści skonsumować. Przy czym dąży się do maksymalizacji korzyści i minimalizacji kosztów ${ }^{16}$. Według P. Doyla tworzenie wartości dla klienta musi koncentrować się na trzech kwe$\operatorname{stiach}^{17}$ :

- klient wybiera dostawcę, który w jego odczuciu oferuje mu największą wartość;

- klienta nie motywuje sam produkt, ale możliwość zaspokojenia potrzeby;

- bardziej korzystne jest budowanie długookresowych relacji niż koncentrowanie się na pojedynczych transakcjach.

Współczesne kreowanie wartości dla klienta wykracza daleko poza koncepcję tzw. „4P”. Kompleksowe podejście do tworzenia wartości dla klienta obejmuje więc ${ }^{18}$ :

- wartość funkcji - dopasowanie produktu do indywidualnych potrzeb i oczekiwań;

- wartość formy - klient uczestniczy w wyborze kształtu, wielkości, stylistyce, wyposażeniu, określa warunki wygody użytkowania produktu;

- wartość czasu - dostępność oferty w czasie wygodnym dla klienta lub kiedy go potrzebuje;

- wartość miejsca - dostarczenie produktów do miejsca odpowiadającego wygodzie zakupu lub gdzie klient go potrzebuje;

- wartość posiadania - zróżnicowanie sposobów przenoszenia prawa do użytkowania produktu ze sprzedawcy lub producenta na nabywcę;

- wartość komunikacji - dostosowanie informacji o ofercie, warunkach użytkowania produktu, warunków nabywania do indywidualnych potrzeb klienta oraz rozstrzyganie wątpliwości klienta, kiedy je ma;

- wartość edukacji - edukacja klientów w celu lepszego wykorzystania funkcji produktu;

- wartość doświadczenia - doznania klientów w okresach przed nabyciem i w trakcie eksploatacji produktu.

Model wartości dla klienta można zbudować na klasycznej koncepcji struktury produktu autorstwa $\mathrm{Th}$. Lewitta i rozwiniętej przez $\mathrm{Ph}$. Kotlera oraz koncepcji L. de Chernatony`ego i M. McDonalda ${ }^{19}$. Model ten przedstawia cztery poziomy wartości dla klienta, na których rozgrywa się współczesna konkurencja

\footnotetext{
${ }^{16} \mathrm{Ph}$. Kotl e r, Marketing, Gebethner \& Ska, Warszawa 1994, s. 33.

${ }^{17}$ P. D o y le, Marketing wartości, Felberg SJA, Warszawa 2003, s. 85.

${ }^{18}$ B. Dobiegała-Korona, T. Doligalski (red), Zarzqdzanie wartościq klienta. Pomiar i strategie, Poltext, Warszawa 2010, s. 26-27.

19 Por. J. Altkorna (red.), Podstawy marketingu, Instytut Marketingu, Kraków 2006, s. 114-118 oraz Ph. Kotle r, op. cit., s. 400-401.
} 
między przedsiębiorstwami i ich sieciami. Są to: wartość podstawowa, wartość dodatkowa, wartość poszerzona o obsługę klienta, wartość oparta na relacjach (zob. tab. 2).

Przeprowadzone badania wskazują, że w przypadku wielu produktów i usług aż 80\% (według innych danych 70\%) wartości postrzeganej przez klienta związane jest $\mathrm{z}$ takimi elementami produktu jak usługi, marka czy stworzone przez przedsiębiorstwo relacje $\mathrm{z}$ klientami. $\mathrm{Z}$ drugiej strony, koszty tworzenia i dostarczania klientom tych dodatkowych korzyści stanowią około $20 \%$ (odpowiednio $-30 \%$ ) kosztów wytwarzania samego produktu ${ }^{20}$.

Model wartości dla klienta

\begin{tabular}{|c|c|c|}
\hline $\begin{array}{l}\text { Poziom warto- } \\
\text { ści dla klienta }\end{array}$ & Charakterystyka & $\begin{array}{c}\text { Narzędzia } \\
\text { kreacji wartości }\end{array}$ \\
\hline $\begin{array}{l}\text { Wartość pod- } \\
\text { stawowa }\end{array}$ & $\begin{array}{l}\text { Określa podstawową korzyść, jaką otrzymuje } \\
\text { klient za daną cenę. Konkurencję na tym poziomie } \\
\text { wartości spotyka się coraz rzadziej (np. na ryn- } \\
\text { kach dóbr masowych). }\end{array}$ & Cena produktu. \\
\hline $\begin{array}{l}\text { Wartość dodat- } \\
\text { kowa }\end{array}$ & $\begin{array}{l}\text { Obejmuje dodatkowe korzyści dla klienta wynika- } \\
\text { jące z dodatkowych funkcji produktu. Konkuren- } \\
\text { cja na tym poziomie wartości jest obecnie spoty- } \\
\text { kana najcześciej. W konkurowaniu coraz mniejszą } \\
\text { rolę odgrywa cena, a firmy starają się dostosowá } \\
\text { oferowana wartość do zróżnicowanych potrzeb } \\
\text { i oczekiwań klientów }\end{array}$ & $\begin{array}{l}\text { Opcje funkcji do wyboru przez } \\
\text { klienta, wzornictwo, opakowanie, } \\
\text { produkty i usługi komplementar- } \\
\text { ne, warunki gwarancji, warunki } \\
\text { płatności itp. }\end{array}$ \\
\hline $\begin{array}{l}\text { Wartość posze- } \\
\text { rzona o obsługę } \\
\text { klienta }\end{array}$ & $\begin{array}{l}\text { Obejmuje wartość podstawowa i dodatkową } \\
\text { poszerzoną o obsługe klienta. Usługi te towarzy- } \\
\text { szą produktowi w całym jego cyklu życia u klien- } \\
\text { ta, będąc źródłem dodatkowych korzyści, ale } \\
\text { i kosztów, które musi ponieść klient, aby z nich } \\
\text { skorzystać }\end{array}$ & $\begin{array}{l}\text { Usługi poprzedzające sprzedaż, } \\
\text { towarzyszące sprzedaży i nastę- } \\
\text { pujące po sprzedaży np. projek- } \\
\text { towanie, doradztwo, dostawa, } \\
\text { serwis }\end{array}$ \\
\hline $\begin{array}{l}\text { Wartość oparta } \\
\text { na relacjach }\end{array}$ & $\begin{array}{l}\text { Jest to poziom wartości, w którym pojawiają się } \\
\text { korzyści i koszty związane z relacjami, które } \\
\text { wiążą klienta z przedsiębiorstwem, pośrednikami } \\
\text { w kanałach dystrybucji oraz z innymi klientami. }\end{array}$ & $\begin{array}{l}\text { Marka produktu, wizerunek } \\
\text { i reputacja firmy, relacje klienta } \\
\text { z firma, wizerunek i reputacja } \\
\text { kanałów dystrybucji, relacje } \\
\text { klienta z kanałami dystrybucji, } \\
\text { relacje między samymi klienta- } \\
\text { mi. }\end{array}$ \\
\hline
\end{tabular}

Źródło: opracowanie własne na podstawie M. Szy mura-Tyc, Marketing we wspótczesnych procesach tworzenia wartości dla klienta i przedsiębiorstwa, Wydawnictwo AE Katowice, Katowice 2006, s. 80-83.

Wyróżnienie czterech poziomów wartości dla klienta pozwala na ukierunkowanie aktywności przedsiębiorstwa na te obszary, które dotyczą kreowania wartości na poziomie wartości dodatkowej poszerzonej o obsługę klienta i rela-

${ }^{20}$ Zob. L. de Chernatony, M. McDonald, Creating Powerful Brands, Batterworth Heineman, Oxford 1994, s. 5. 
cje wiążące klienta $\mathrm{z}$ przedsiębiorstwem i jego partnerami. W konsekwencji pozawala to skuteczniej budować przewagę konkurencyjną przedsiębiorstwa na danym rynku.

We współczesnej gospodarce mamy do czynienia z sytuacją, w której relacje między przedsiębiorstwami przybierają postać od klasycznie rozumianej konkurencji po szeroko zakrojoną współpracę. Granice przedsiębiorstw nie są wyraźnie określone, gdyż przepływ informacji w czasie rzeczywistym rozmywa ich ramy organizacyjne. Uważa się, że wartość dla klienta tworzona przez sieć przedsiębiorstw powstaje dzięki stworzeniu dostępu do informacji, rynku i technologii, możliwości podziału ryzyka oraz efektywności skali i zakresu działania, dzielenia się wiedza, większej efektywności transakcji, uczestnictwa klientów w kształtowaniu wartości.

\section{PODSUMOWANIE}

Współczesny biznes skupia się na planowaniu, tworzeniu i pielęgnowaniu relacji z klientami i partnerami biznesowymi. Coraz mniej uwagi przywiązuje się do jednorazowej transakcji, a znaczenia nabiera budowanie partnerskich relacji. One bowiem pozwalają na zaspokojenie potrzeb wymagających klientów, a także na obniżenie kosztów, zwiększenie efektywności wykorzystania zasobów, obniżenie ryzyka, czy też uzyskanie dostępu do nowych technologii. To wszystko warunkuje kreację wartości współczesnych firm w turbulentnym i wymagającym otoczeniu.

Nowoczesne przedsiębiorstwo (sieć) powinno budować własną, niepowtarzalną mapę wartości dla klientów, obejmującą zbiór i kolejność priorytetów, ponieważ klienci oczekują indywidualnej obsługi. Wartości dla klienta mogą być poszerzane, doskonalone i różnicowane w ofertach dla grup oraz indywidualnych klientów. Przedsiębiorstwo (sieć przedsiębiorstw) powinno kreować taki zestaw wartości, aby zaspokoić potrzeby swoich klientów, a tym samym wyróżnić się na tle konkurentów.

\section{BIBLIOGRAFIA}

Alt k o r n a J. (red), Podstawy marketingu, Instytut Marketingu, Kraków 2006.

Bengtsson M., Kock S., Coopetition in Business Networks - to Cooperate and Compete Simultaneously, „Industrial Marketing Management” 2000, Vol.14, No. 3.

B lażlak R., Struktury sieciowe a innowacyjność przedsiębiorstw, [w:] K. O w c z a re k (red.), Klastry w gospodarce regionu, Monografie Politechniki Łódzkiej, Łódź 2010.

B rilm an J., Nowoczesne koncepcje i metody zarzqdzania, PWE, Warszawa 2002.

B r zezińs ki M., Organizacja i sterowanie produkcja, Placet, Warszawa 2002. 
de Chernatony L., McDonald M., Creating Powerful Brands, Batterworth Heineman, Oxford 1994.

Dobiegała-Korona B., Doligalski T. (red.), Zarzqdzanie wartościq klienta. Pomiar i strategie, Poltext, Warszawa 2010.

D obi e gała-Korona B., Herman A. (red.), Wspótczesne źródta wartości przedsiębiorstwa, Difin, Warszawa 2006.

Dobiegała-Korona B., Wartość klienta czy wartość dla klienta?, „Kwartalnik Nauk o Przedsiębiorstwie", październik 2006, nr 1.

D o yle P., Marketing wartości, Felberg SJA, Warszawa 2003.

D ru cker P. F., Myśli przewodnie Druckera, MTBiznes, Warszawa 2002.

Głu sze k E., Zarzqdzanie zasobami niematerialnymi przedsiębiorstwa, Wydawnictwo AE we Wrocławiu, Wrocław 2004.

Górlac zy k A., Leif Edvinsson na konferencji Skandii, http://ceo.cxo.pl/news/39471/Leif.Edvinsson.na.konferencji.Skandii.html

Górzy ńs ki M., Pander W., Koć P., Tworzenie zwiazków kooperacyjnych między MSP oraz. MSP $i$ instytucjami otoczenia biznesowego, PARP, Warszawa 2006.

Hill C. W. L., Jon e s T. M., Stakeholder - Agency Theory, „Journal of Management Studiem” 1992, Vol. 2.

Hofman-B ang P., Martin H., IC Rating na tle innych metod oceny kapitatu intelektualnego,

http://www.e-mentor.edu.pl/artykul/index/numer/11/id/193

J e r ze mo w s k a M., Nadzór korporacyjny, PWE, Warszawa 2002.

Kardas J. S., Budowanie relacji w zarzqdzaniu zasobami ludzkimi, Wydawnictwo Studia Emka, Warszawa 2009.

K otle r Ph., Marketing, Gebethner \& Ska, Warszawa 1994.

Nie mczyk J., Wyróżniki, budowa i zachowania strategiczne układów outsourcingowych, AE, Wrocław 2006.

Nowak D., Zarzadzanie międzyorganizacyjnymi relacjami kooperacyjnymi $w$ przedsiębiorstwach przemysłowych, Wydawnictwo UE w Poznaniu, Poznań 2012.

Prah a lad C. K., R a ma s w a m y V., Przyszłość konkurencji, PWE, Warszawa 2005.

S zablewski A., Zarzqdzanie wartościa przedsiębiorstwa, „Kwartalnik Nauk o Przedsiębiorstwie", październik 2006, nr 1.

Szymura-Tyc M., Marketing we wspótczesnych procesach tworzenia wartości dla klienta i przedsiębiorstwa, Wydawnictwo AE Katowice, Katowice 2006.

Woźniak-Sobczak B. (red.), Instrumenty zarzqdzania przedsiębiorstwem przez finanse, Wydawnictwo Akademii Ekonomicznej w Katowicach, Katowice 2010.

Anna Kwiecień,

Katarzyna Żak

\section{BUILDING RELATIONSHIPS THE NETWORK STRUCTURES IN THE PROCESS OF CREATING VALUE CUSTOMER AND COMPANY}

The modern business is focused on planning, developing and nurturing relationships with clients and business partners. Less and less attention is paid to a single transaction, and the most importance is a building of partnerships. Because they allow you to meet the needs of demanding customers, as well as to reduce costs, increase resource efficiency, reduce risk, or to gain access to new technologies. It all determines the creation of today's businesses in turbulent and challenging environment. 
Modern enterprise /network/ should build their own unique map value for customers, including the collection and the order of priority, because customers expect personalized service. Customer value can be expanded, improved and differentiated in offers for groups and individual clients. Company /business network/ should create a set of values to meet the needs of its customers, and thus stand out from competitors.

Key words: relations, network structures, client, customer value, value based management. 